\title{
The Canadian Journal for the Scholarship of Teaching and Learning
}

Fall 09-30-2020

\section{CJSoTL at 10: A Quantitative Analysis of Authorship, Genre, and Impact}

Michael P.A. Murphy

University of Ottawa, mmurp078@u0ttawa.ca

Follow this and additional works at: https://www.cjsotl-rcacea.ca https://doi.org/10.5206/cjsotl-rcacea.2020.2.8627

Recommended Citation

Murphy, M. P. A. (2020). CJSoTL at 10: A quantitative analysis of authorship, genre, and impact. The Canadian Journal for the Scholarship of Teaching and Learning, 11(2). https://doi.org/10.5206/cjsotl-rcacea.2020.2.8627 


\title{
CJSoTL at 10: A Quantitative Analysis of Authorship, Genre, and Impact
}

\begin{abstract}
On the occasion of the completion of the tenth volume of The Canadian Journal for the Scholarship of Teaching and Learning, we have the opportunity to reflect on the kind of scholarly community that The Canadian Journal for the Scholarship of Teaching and Learning has created through its publication of particular articles. One way to attempt this task is through a quantification of different elements of the journal's history. While the numbers cannot tell us about the internal life of the journal, analysis of the journal's output can help identify areas of strength and weakness in the journal's past and areas of focus for the future.

À l'occasion de l'achèvement du dixième volume de La revue canadienne sur l'avancement des connaissances en enseignement et en apprentissage, nous avons l'occasion de réfléchir sur le type de communauté savante que La revue sur l'avancement des connaissances en enseignement et en apprentissage a créée par le biais de la publication d'articles particuliers. Une manière de tenter de répondre à cette question est de quantifier divers éléments de l'historique de la revue. Alors que les chiffres ne peuvent pas nous dire grand chose sur la vie interne de la revue, l'analyse des résultats de la revue peut nous aider à identifier les forces et les faiblesses dans le passé de la revue ainsi que les domaines sur lesquels nous devrions nous pencher à l'avenir.
\end{abstract}

\section{Keywords}

scholarship of teaching and learning, language, publishing in SoTL, genre; avancement des connaissances en pédagogie, langue, publier en ACEA, genre 
On the occasion of the tenth volume of The Canadian Journal for the Scholarship of Teaching and Learning (CJSoTL), we have the opportunity to reflect on the kind of scholarly community that CJSoTL has created through its publication history to this point. In this article, I would like to reflect on the journal's anniversary through two related questions. First, is the journal living up to its stated mission? Second, (how) is the journal making an impact? While there are multiple ways to approach these questions, the quantitative analysis employed in this article allows for clear impact assessment in terms of citation counts, authorship characteristics, and genre breakdowns.

The first section outlines the mission of the journal as articulated in editorial introductions - a commitment to bilingualism and representing the diversity of scholarship of teaching and learning underway at Canadian institutions. The method section reviews the data analysis and, acknowledging that scientometric analysis is uncommon in the scholarship of teaching and learning, introduces the key concepts used in the impact analysis. The third section presents authorship findings, including by gender, frequency of coauthorship, and linguistic demographics. This section speaks both to the bilingualism element of the journal's mission, and offers an authorship profile of who publishes in the journal. The fourth section reviews the different genres of publication, which offers an important measure of the journal's commitment to representing diverse ways of engaging in scholarship of teaching and learning research. Because this investigation seeks to understand not only if the journal is living up to its mission but also if the efforts are having an impact, analysis of the citation patterns by genre and year are outlined in the appropriate sections. While numbers alone cannot grant insight into the internal life of the journal, quantitative analysis of the journal's impact can help identify areas of strength and areas for improvement after the first decade.

\section{The Mission of CJSoTL}

In the 2010 inaugural issue of CJSoTL, co-editors Dieter Schönwetter and Dianne Bateman contextualize the rise of the scholarship of teaching and learning (SoTL) publications, including relevant developments in the Canadian context, and set out the mission of the new journal. From the early 1990s through to 2008, there was a growing sense of the importance of studying teaching and learning, from Ernest Boyer's Scholarship Reconsidered to the founding of the Journal of Scholarship of Teaching and Learning and the International Journal for the Scholarship of Teaching and Learning. In the Canadian academy, the Society for Teaching and Learning in Higher Education became a leading voice in organizing these conversations. The journal was thus founded with the "primary purpose [being] to publish quality peer-reviewed articles and essays in French and English" with a "focus is primarily on SoTL in Canadian post-secondary institutions" (Schönwetter \& Bateman, 2010, p. 1). The editors called for a "uniquely Canadian discussion” to take place (p. 4) and proudly declare that "the scientific study of teaching in higher education has a Canadian home” in the journal's pages (p. 4). The journal has always presented itself as a premier outlet for SoTL research taking place in Canada and on Canadian subjects, and claims a Canadian identity from on geographical-empirical terms. These claims were most recently restated in Beth Marquis' introductions to issues 10.1 and 10.2, where she highlights the mission of the journal as being "to grow, support, and celebrate teaching and learning scholarship in Canada" (Marquis, 2019b, p. 1), and describes an ongoing effort to "collectively develop our portrait of Canadian SoTL” (Marquis, 2019a, p. 1). 
The definition of "Canadian" in geographical terms does not mean that the journal does not have unique characteristics. Indeed, a core part of the mission was to provide a forum for bilingual discussion that is largely lacking in the broader SoTL journal ecosystem-although the success of this will be discussed later. But a decision to represent the diversity of inquiry into teaching and learning taking place at universities in Canada meant that articles published in CJSoTLhave included a number of different disciplinary, methodological, and epistemological approaches. In addition to editorial messages supporting the importance of methodological and genre diversity (e.g., Marquis, 2019a, 2019b), the journal has housed special issues dedicated to broadening the scope of what counts as scholarship of teaching and learning research. In 2015, the journal published a special issue on the role of arts and humanities approaches to the scholarship of teaching and learning (e.g., Chick 2015; Potter \& Wuetherick, 2015). A special issue on the theme of collaborative writing drew out novel perspectives around shared topics of interest, foregrounding the importance of scholarly dialogue (e.g., Healey 2017; Simmons \& Marquis, 2017), and a 2018 special issue on ePortfolios demonstrated a range of experiences on that theme (e.g., Petit et al., 2018).

Reviewing the mission indicates that efforts have been successful to live up to half of the mission, as the journal has represented the diverse articulations of how SoTL is practiced in Canada. But two major questions remain - is the journal having an impact? And to what extent is the journal living up to its mission of offering an outlet for pedagogical conversations in both official languages? Both of these questions are appropriately addressed quantitatively, and it is to that element of the investigation that our attention now turns.

\section{Methodology}

The study was conducted through the manual coding of each article published by CJSoTL from 2010-2019. All citation data was gathered from searches on Google Scholar. While issues have been noted with the cleanliness of data in Google Scholar (e.g., Bar-Ilan, 2008), it is widely accessible and a recent study found that "Google Scholar provides the most comprehensive coverage" compared to other databases (Harzing \& Alankagas, 2016, p. 801). Further, because the primary use of some SoTL research is in practical pedagogical guides rather than only scholarly literature, the wider inclusion criteria of Google Scholar more accurately reflects the relevant community for SoTL impact analysis than a database limited only to peer-reviewed articles.

While many of the metrics are a straightforward presentation of citation numbers, or calculated percentages/mean values/standard deviations, etc., I have also included Hirsch-type indices for the genres of publication. First introduced for the analysis of individual scholars' impact (Hirsch 2005), the H-index reflects the number of papers with a citation number greater than or equal to $h$. Subsequent developments quickly applied an H-type index (Braun et al., 2006) to assess the impact of journals. Arguments in favour of an $\mathrm{H}$-index over a raw citation count is that the $\mathrm{H}$ index demonstrates consistency in publishing impactful work, whereas a single "hit" might result in a greatly inflated citation count. While journal impact factors are typically calculated by dividing the total number of citations received by articles published in that journal over the previous three or five years by the number of articles, H-type journal indices similarly hedge against one-hit wonders inflating the impact assessment of a journal. I apply an $\mathrm{H}$-type index to each published genre in CJSoTL archives, based on citation data from Google Scholar, following this same logic. In addition, drawing from the arguments of Weale et al. (2008) on journal impact assessment, I have included a calculation of percentage cited both for year-over-year comparisons and by genre. 


\section{Authorship}

The discussion of authorship will be analyzed year-over-year in Table 1, along with annual citation and language patterns. The majority of articles published in CJSoTLhave been written by two or more authors, reflecting a pattern of collaborative writing. The highest rate of coauthorship is found in 2017, partially due to the special issue on collaborative writing groups. In concert with patterns more widely identified in the scholarship of teaching and learning (e.g., McKinney \& Chick, 2010; Myers, 2008), the majority of articles published in CJSoTLhave had a female first author (for coauthored works) or a female as the only author. This figure has modulated somewhat, but never dropped below 70\% and reached as high as 89\% (2016). Canadian authorship-defined as the percentage of first or only authors affiliated with a Canadian institution at time of publication - has consistently remained at a very high level, never dropping below 90\%. For the years of 2011, 2014, 2016, and 2019, all articles published had a Canadian institution-affiliated first or only author.

With the exception of 2018, an outlier following more editorial material written in French than is typical, the representation of francophone scholarship in CJSoTL has been very low. The most common outcome, found in 6 of the journal's first 10 years, sees the entire volume was comprised of English-language articles. The second most common outcome sees only one article included. As Maheux-Pelletier et al. (2017) note, despite a formal position of bilingualism, CJSoTL does not live up to its billing.

More positive news is to be found in the analysis of citation counts. Examining the number of citations that articles receive is an inexact science (as there is nothing in the numbers that distinguishes an approving from a disapproving citation), but a variety of quantitative measures of citation at the very least can help reveal the extent to which the published materials are seen as worth engaging. Using citation as a proxy to assess an article's impact is useful because of how frequently articles are never or rarely cited. A review published in Nature found that $43.83 \%$ of all papers in the Web of Science had zero citations and a further 31.63\% had between 1-9 citations (van Noorden et al., 2014), meaning that-in rough terms - the items with 10 citations or more (i10) index identifies the top quartile of all published research. Across the journal's history, 46 items would place in the top quartile, including thirty from the first four volumes alone! More generally, the percentage of items published in CJSoTL that are cited consistently remain 30-50\% above the average (excluding the latest two years for recency bias). The impact analysis here demonstrates that CJSoTL has, in fact, contributed to the broader field of the scholarship of teaching and learning. These data reflect well upon the ability of a relatively young scholarly journal to make an outsized contribution. On the occasion of the journal's tenth anniversary, the work of the editors, reviewers, authors, and readers should be recognized for this achievement. 
Table 1

Article Characteristics and Impact by Year.

\begin{tabular}{|c|c|c|c|c|c|c|c|c|}
\hline Year & $\begin{array}{c}\text { Total } \\
\text { Articles }\end{array}$ & $\begin{array}{l}\text { Articles in } \\
\text { French }\end{array}$ & $\begin{array}{c}\text { \# of } \\
\text { Authors, } \\
\text { Mean(SD) }\end{array}$ & $\begin{array}{c}\text { Female First } \\
\text { or Only } \\
\text { Author }{ }^{1}\end{array}$ & $\begin{array}{c}\text { Canadian } \\
\text { First or } \\
\text { Only } \\
\text { Author }^{2}\end{array}$ & $\%$ Cited $^{3}$ & $\begin{array}{l}\text { Citation, } \\
\text { Mean(SD) }\end{array}$ & i10 \\
\hline 2010 & 16 & 1 & $2(3.03)$ & $75 \%$ & $93.75 \%$ & $81.25 \%$ & $9(23.79)$ & 8 \\
\hline 2011 & 14 & 0 & $2(1.16)$ & $78.57 \%$ & $100 \%$ & $85.71 \%$ & $14(23.96)$ & 8 \\
\hline 2012 & 14 & 1 & $2(1.76)$ & $71.43 \%$ & $92.86 \%$ & $85.71 \%$ & $9.5(15.8)$ & 7 \\
\hline 2013 & 14 & 0 & $2(0.77)$ & $71.43 \%$ & $92.86 \%$ & $78.57 \%$ & $6.5(8.16)$ & 7 \\
\hline 2014 & 10 & 0 & $1.5(2.61)$ & $80 \%$ & $100 \%$ & $90 \%$ & $7(6.27)$ & 3 \\
\hline 2015 & 31 & 0 & $2(1.24)$ & $70.97 \%$ & $93.45 \%$ & $90.32 \%$ & $5(12.41)$ & 8 \\
\hline 2016 & 19 & 0 & $2(2.22)$ & $89.47 \%$ & $100 \%$ & $78.95 \%$ & $2(4.91)$ & 3 \\
\hline 2017 & 35 & 2 & $3(2.47)$ & $77.14 \%$ & $91.43 \%$ & $82.86 \%$ & $3(2.78)$ & 1 \\
\hline 2018 & 33 & 7 & $3(1.64)$ & $84.85 \%$ & $93.94 \%$ & $54.55 \%$ & 1(4.69) & 1 \\
\hline 2019 & 23 & 0 & $2(1.61)$ & 73.91\% & $100 \%$ & 17.39\% & $0(0.51)$ & 0 \\
\hline
\end{tabular}

Note. ${ }^{1}$ Determined by pronouns associated with author official biography, faculty profile or similar. ${ }^{2}$ Determined by institutional affiliation at time of publication. ${ }^{3}$ All citation count information from Google Scholar, current as of 6 December 2019. Calculations by author. 


\section{Genre}

Given the growing attention paid to the genres of writing in the scholarship of teaching and learning (e.g., Healey et al., 2019; Murphy, 2019), an analysis of the six genres published in CJSoTL can offer insight into the impact of particular areas of the journal. The six genres are defined below:

- Research Paper: evidence-based work presenting original results or arguments of relevance to teaching and learning in higher education. As a multidisciplinary journal, CJSoTL welcomes research from a broad range of methodological traditions and disciplinary perspectives.

- Research Note: presenting early findings or methodological innovations of ongoing research projects.

- Essays: argumentative or expository. Normally, essays will focus on issues related to the development, use, and support of SoTL in post-secondary education (i.e., they will focus on SoTL itself as a field or area of research and practice).

- Book Reviews: academic review of books on or about themes in SoTL in post-secondary education which are relevant to the Canadian context. Priority may be given to books by Canadian authors or which have particular relevance for the Canadian context.

- Calls for Collaboration: literature supported papers...outlining research questions of substantial national interest and inviting collaboration.

- Other Submissions: the journal encourages innovation and creativity in forms of publication and will entertain proposals for other types of papers from authors. ${ }^{1}$

- Editorials: While CJSoTL does not accept unsolicited submissions under the editorial category, each issue begins with an editorial, and some special issues have included other prefatory essays under the tag of "editorial."

As seen below in table 2, the largest number of items published have taken the form of the traditional research paper, by a large margin. The second most frequent form is editorial material, including both the introduction to each issue and the inclusion of prefatory material to special issues. Third, we find the essay, followed by research notes, book reviews, and "other.”

\footnotetext{
${ }^{1}$ While "Calls for Contribution" are welcomed in the journal's author notes, none of the published items are tagged as such. All information except for the "editorial” category taken from the CJSoTL website at https://ojs.lib.uwo.ca/index.php/cjsotl_rcacea/about/submissions. Last Accessed 8 April 2020.
} 
Table 2

Article Characteristics and Impact by Genre

\begin{tabular}{|c|c|c|c|c|c|c|c|}
\hline Genre & Number & $\begin{array}{c}\% \\
\text { French }\end{array}$ & H-type & i10 & \% cited & $\begin{array}{c}\text { Total } \\
\text { Citations1 }\end{array}$ & Citations/item \\
\hline $\begin{array}{l}\text { Research } \\
\text { Paper }\end{array}$ & 156 & $5.12 \%$ & 17 & 37 & $80.13 \%$ & 1156 & 7.41 \\
\hline $\begin{array}{l}\text { Research } \\
\text { Note }\end{array}$ & 6 & 0 & 3 & 2 & $66.67 \%$ & 56 & 9.33 \\
\hline Editorial & 27 & $7.45 \% 2$ & 3 & 0 & $29.63 \%$ & 21 & 0.78 \\
\hline Essay & 13 & $7.69 \%$ & 6 & 6 & $84.62 \%$ & 243 & 18.69 \\
\hline $\begin{array}{l}\text { Book } \\
\text { Review }\end{array}$ & 3 & 0 & 0 & 0 & 0 & 0 & 0 \\
\hline Other & 4 & 0 & 3 & 3 & $75 \%$ & 30 & 7.5 \\
\hline
\end{tabular}

Note. ${ }^{1}$ All citation count information from Google Scholar, current as of 6 December 2019. H-type, i10, \% Cited calculations by author. ${ }^{2}$ For this item only, coding is "French first or only" as language used.

Testing the impact of different genres highlights both the high citation rate for the journal and the difference between citation metrics. The H-type, i10, and total citation measurements reveal the research paper as the highest-impact genre, where as \% cited and citations/item point to the essay genre. All genres (except editorial material and book reviews) are higher than average in percentage cited. This table demonstrates consistent impact across the three major non-editorial genres of the journal. While the familiar genre of the research paper takes up the most space in the journal's pages by a large margin, essays on timely issues can generate much discussion and citation.

Indeed, while research papers remain the main currency of the scholarship of teaching and learning, this impact assessment of genres published in CJSoTL reveals that essays have been consistently cited, with some very high-impact pieces. For example, Betty J. Barrett's (2010) essay “Is 'Safety' Dangerous? A Critical Examination of the Classroom as a Safe Space” has been cited 87 times, and "Diverse Methodological Approaches and Considerations for SoTL in Higher Education” by Harry Hubball and Anthony Clark (2010) has been cited 66 times ${ }^{2}$ —both well into the top $10 \%$ of all-time most highly cited as estimated by the Nature review. As the scholarly discussion of writing genres in the scholarship of teaching and learning continues, the case study of CJSoTL offers an important empirical case in defence of multiple modes of expression. Beyond a normative argument for allowing multiple modes of intervention into debates around teaching and learning, journals may indeed benefit from publishing high-impact interventions in lesstraditional formats (in addition to research papers).

\section{Concluding Thoughts: Celebration and the Politics of Language}

This short reflection on the first ten years of CJSoTL offers a quantitative snapshot of the journal's history. Brevity and simple statistics mean that this is far from a final word on the status of the journal, but rather a call to continued reflexivity about what it means to be involved with a scholarly journal on teaching and learning in Canada. I have three concluding thoughts to share. First, through ten years, CJSoTL community-editors, reviewers, authors, and readers_-should be proud of the impact that the journal has made in the broader scholarship of teaching and learning

\footnotetext{
${ }^{2}$ Figures accurate as of 6 December 2019.
} 
world, as evidenced by the citation numbers. Second, from a normative position, the commitment to a diversity of genres, and the general success across multiple modes of expression is a positive contribution to the field and CJSoTL can serve as a case study for future study of genre in the scholarship of teaching and learning as well as an example for other outlets.

The major challenge posed for the next ten years lies in the need for greater linguistic inclusivity. While billed as a bilingual journal, this has not translated into a significant volume of French-language publication. As studies in academic more generally have noted (Altbach, 2007; Stockemer \& Wigginton, 2019), pressures to publish in English have created a normalization of one language at the expense of others. The politics of language in the Canadian academy lie at the heart of the question of access, and have been explored at length in disciplines such as politics and international relations (e.g., D’Aoust, 2012; Grondin, 2014; Grondin et al., 2012; Murphy \& Wigginton, 2020; Turenne Sjolander, 2007). While the existing data cannot tell us what threshold would mark a truly bilingual journal, less than $5 \%$ of non-editorial content is insufficient. If CJSoTL wishes to foster an open, engaging, and productive dialogue for all Canadian institutions engaged in the scholarship of teaching and learning, much more must be done to include francophone voices.

\section{References}

Altbach, P. G. (2007) The imperial tongue: English as the dominating academic language. Economic \& Political Weekly, 42(36), 3608-3611. https://doi.org/10.6017/ihe.2007.49.7986

Bar-Ilan, J. (2008). Which h-index? - a comparison of WoS, Scopus, and Google Scholar. Scientometrics, 74(2), 257-271. https://doi.org/10.1007/s11192-008-0216-y

Barrett, B. J. (2010). Is 'safety' dangerous? A critical examination of the classroom as safe space. The Canadian Journal for the Scholarship of Teaching and Learning, 1(1), 1-12. http://dx.doi.org/10.5206/cjsotl-rcacea.2010.1.9

Braun, T., Glanzel, W., \& Schubert, A. (2006). A Hirsch-type index for journals. Scientometrics, 69(1), 169-173. https://doi.org/10.1007/s11192-006-0147-4

Chick, N. L. (2015). Holding it up to the light: looking at learning through the lenses of the arts and humanities. The Canadian Journal for the Scholarship of Teaching and Learning, 6(2), 1-7. http://dx.doi.org/10.5206/cjsotl-rcacea.2015.2.3

D’Aoust, A. M. (2012). Accounting for the politics of language in the sociology of IR. Journal of International Relations and Development, 15, 120-131. https://doi.org/10.1057/jird.2011.30

Grondin, D. (2014). Les langues comme institutions de savoir/pouvoir dans les études critiques de la sécurité: Le récit d’un initié/profane. Critical Studies on Security, 2(1), 59-80. https://doi.org/10.1080/21624887.2013.856554

Grondin, D., D’Aoust, A. M., \& Racine-Sibulka, P. (2012). La discipline francophone des Relations Internationales au Québec et au Canada: Pistes des refléxion sur les enjeux et les dilemmes linguistiques liés au marché du travail. Politique et Sociétés, 31(3), 9-37. https://doi.org/10.7202/1014958ar

Harzing, A., \& Alankagas, S. (2016). Google Scholar, Scopus, and the Web of Science: A longitudinal and cross-disciplinary comparison. Scientometrics, 106, 787-804. https://doi.org/10.1007/s11192-015-1798-9 
Healey, M. (2017). Reflections on the development of international collaborative writing groups (ICWGs) about teaching and learning in higher education. The Canadian Journal for the Scholarship of Teaching and Learning, 8(2), 1-5. https://doi.org/10.5206/cjsotl-rcacea.2017.2.3

Healey, M., Matthews, K. E., \& Cook-Sather, A. (2019). Writing scholarship of teaching and learning articles for peer-reviewed journals. Teaching \& Learning Inquiry, 7(2), 28-50. https://doi.org/10.20343/teachlearninqu.7.2.3

Hirsch, J. E. (2005). An index to quantify an individual's scientific output. Proceedings of the National Academy of Sciences of the USA, 102, 16569-16572. https://doi.org/10.1073/pnas.0507655102

Hubball, H., \& Clarke, A. (2010). Diverse methodological approaches and considerations for SoTL in higher education. The Canadian Journal for the Scholarship of Teaching and Learning, 1(1), 1-11. https://doi.org/10.5206/cjsotl-rcacea.2010.1.2

Maheux-Pelletier, G., Rukholm, V., Groen, J. F., \& Vezina, N. (2017) Nested within or swallowed up: Le dilemme des chercheurs francophones en pedagogie postsecondaire au Canada. The Canadian Journal for the Scholarship of Teaching and Learning, 8(2), 1-16. https://doi.org/10.5206/cjsotl-rcacea.2017.2.7

Marquis, E. (2019a). Canadian SoTL in 10 parts: An introduction to issue 10.2. The Canadian Journal for the Scholarship of Teaching and Learning, 10(2), 1-3. https://doi.org/10.5206/cjsotl-rcacea.2019.2.8208

Marquis, E. (2019b). Tin anniversaries and teaching and learning scholarship: An introduction to issue 10.1. The Canadian Journal for the Scholarship of Teaching and Learning, 10(1), 1-3. https://doi.org/10.5206/cjsotl-rcacea.2019.1.7958

McKinney, K., \& Chick, N. L. (2010). SoTL as women's work: What do existing data tell us? International Journal for the Scholarship of Teaching and Learning, 4(2), 1-14. https://doi.org/10.20429/ijsotl.2010.040216

Murphy, M. P. A. (2019). Should we prepare students for active learning classrooms? An unresolved question and two provocations. International Journal for Academic Development, 1-12. https://doi.org/10.1080/1360144X.2019.1668397

Murphy, M. P. A. \& Wigginton, M. J. (2020). Canadian International Relations, American social science? Evidence from academic journals and comprehensive reading lists. International Journal 75(1): 5-23. https://doi.org/10.1177/0020702020917993

Myers, C. B. (2008). College faculty and the scholarship of teaching: Gender differences across four key activities. Journal of the Scholarship of Teaching and Learning, 8(2), 38-51. https://scholarworks.iu.edu/journals/index.php/josotl/article/view/1700

Petit, M., Monney, N., \& Gremion, C. (2018). Le portfolio numérique en enseignement supérieur: Introduction à un numéro spécial de la RCACEA. The Canadian Journal for the Scholarship of Teaching and Learning, 9(3), 1-4. https://doi.org/10.5206/cjsotl-rcacea.2018.3.1

Potter, M. K., \& Wuetherick, B. (2015). Who is represented in the teaching commons? SoTL through the lenses of the arts and humanities. The Canadian Journal for the Scholarship of Teaching and Learning, 6(2), 1-16. https://doi.org/10.5206/cjsotl-rcacea.2015.2.2

Schönwetter, D. J., \& Bateman, D. (2010). An introduction by the editors. The Canadian Journal for the Scholarship of Teaching and Learning, 1(1), 1-9. https://doi.org/10.5206/cjsotl-rcacea.2010.1.1 
Simmons, N., \& Marquis, E. (2017). Promoting and celebrating international SoTL collaborations: An introduction to the special issue. The Canadian Journal for the Scholarship of Teaching and Learning, 8(2), 1-5. https://doi.org/10.5206/cjsotl-rcacea.2017.2.1

Stockemer, D., \& Wigginton, M. J. (2019). Publishing in English or another language: An inclusive study of scholar's language publication preferences in the natural, social, and interdisciplinary sciences. Scientometrics, 118(2), 645-652. https://doi.org/10.1007/s11192-018-2987-0

Turenne Sjolander, C. (2007). Two solitudes? Canadian foreign policy/politique étrangère au Canada. Canadian Foreign Policy Journal, 14(1), 101-108. https://doi.org/10.1080/11926422.2007.9673456

van Noorden, R., Maher, B., \& Nuzzo, R. (2014). The top 100 papers: Nature explores the mostcited research of all time. Nature, 514, 550-553. https://doi.org/10.1038/514550a

Weale, A. R., Bailey, M., \& Lear, P. A. (2004). The level of non-citation of articles within a journal as a measure of quality: A comparison to the impact factor. BMC Medical Research Methodology, 4, 1-8. http://www.biomedcentral.com/1471-2288/4/14 